\title{
Innovative Development of Mobile Application for Qibla Direction Guidance Services Training
}

\author{
Fajar Fathurahman \\ Student of Doctoral Program, Islamic University of Jakarta \\ Correspondent: fajar.fathurahman@gmail.com
}

Submitted : June 28, 2020 Revised : July 15, 2020 Published : July 30, 2020

\begin{abstract}
This study aims to produce a software in the Qibla Direction Determination that is created using a web-based application and can be accessed optimally via an android based-cellular phone. This research uses the Research and Development method by adapting the ADDIE development model which consists of five (5) stages, namely Analysis, Design, Development, Implementation and Evaluation. This Research was conducted on tehnical staff at the office in the Ministry of Religion of Kepulauan Seribu Region. The result of this research trial found that the media that had been developed were suitable for use and made the training process and also its applications easier and more affordable. The results of this study indicate that the use of mobile applications in the Qibla Direction Guide Service Training that is applied with the blended learning model can improve participants' understanding of the concept of calculation Qibla Direction Determination that can be applied interactively, collaboratively and also integratively between science and technology.
\end{abstract}

Keywords: Mobile Application, Blended Learning, Islamic Education

\section{INTRODUCTION}

Working Area of the Ministry of Religion Office of the Kepulauan Seribu Regency Geographically it is located between $106^{\circ} 19^{\prime} 30^{\prime \prime}-106^{\circ} 44^{\prime} 50^{\prime \prime}$ East Longitude and 5 $10^{\prime} 00^{\prime \prime}-5^{\circ}$ $57^{\prime} 00^{\prime \prime}$ South Latitude. Most of the Kepulauan Seribu Regency is ocean with a total area of $4,745.62 \mathrm{~km} 2$, consisting of $8.76 \mathrm{~km} 2$ of island land inhabited by the population, the rest of which are sea islands of sand and coral reefs.

The Seribu Islands Regency Ministry of Religion office is responsible for Raudhatul Athfal, Madrasah Ibtidaiyah, Tsanawiyah and Aliyah and 2 (two) District Office of Religious Affairs, namely KUA Kepulauan Seribu Utara and KUA Kepulauan Seribu Selatan. the two religious affairs offices are in charge of the kelurahan in the Kepulauan Seribu region, there are 6 kelurahan which cover several islands, namely Kelapa islands kelurahan, Harapan islands kelurahan, Panggang islands kelurahan, Tidung islands kelurahan, Pari islands kelurahan, and Untung Jawa islands kelurahan.

The occupation of Kepulauan Seribu Regency is 100\% Muslim. In all inhabited islands there are mosques and prayer rooms with a total of 44 locations. Based on data from the Kepulauan Seribu Statistics Agency in 2020, the total population in the Kepulauan Seribu Administrative District is 24,154 people, consisting of 12,031 men and 12,123 women. Meanwhile, for the average population density of the each Kepulauan Seribu District Administration, which is around 2,776 inhabitants / $\mathrm{km} 2$ with the composition of the population density in the District of South 
Innovative Development of Mobile Application for Qibla Direction Guidance Services Training Fathurahman

Kepulauan Seribu reaching 3,312 inhabitants / km2 and the population density in the District of the North Kepulauan Seribu is 2,487 inhabitants / km2.

Constraints that exist today are still many mosques, prayer rooms and homestay worship facilities owned by Muslims who have not received Qibla direction determination services, at least technical personnel are able to provide Qibla direction determination services, travel constraints / affordability issues in obtaining guidance information and Qibla direction determination service in areas limited by the ocean. These constraints can be grouped into factors as follows:

1. At least officers who are able to provide Qibla direction determination services;

2. Time limitations in providing guidance services for determining the direction of Qibla;

3. Problems of affordability of services due to the limited sea area and transportation;

4. Difficulties in coordination between units of the Office of the Ministry of Religion in the District and other technical matters that affect due to the geographical location of the offices and work units on different islands.

By looking at the geographical and demographic conditions within the Ministry of Religion Kepulauan Seribu Regency, the implementation of Qibla direction guidance training services needs to pay attention to geographical and demographic factors that are restricted to ocean areas as described above. However, observations were obtained that the majority of employees of the Ministry of Religion in the Kepulauan Seribu Regency had smartphones with the availability of internet network signals covering almost the entire island.

In accordance with these factual conditions, in order to realize effective and efficient Qibla direction guidance training services in the Ministry of Religion Office of Kepulauan Seribu Regency, it is necessary to develop a mobile application for Qibla direction guidance service. The developed application is intended to be easily accessible whenever and wherever it is so that geographical limitations can be overcome. Mobile application development has several advantages including the following:

1. Officers can practice determining the direction of Qibla anywhere and anytime;

2. Qibla direction training applications can be used and stored digitally;

3. The Qibla direction training application can be accessed via cellphone and computer;

4. This guidance application makes it easy for participants to understand the concept of the training.

Therefore, this article will discuss how the development of a Mobile Application guidance service for Qibla direction determination which is applied in the training of Qibla guidance services. It is also necessary to conduct a survey after the training to find out how far the level of satisfaction using mobile applications is in an effort to improve the public service performance staff at each Ministry of Religion office in Kepulauan Seribu region. Qibla direction determination training is implemented with blended learning and mobile learning models by making mobile applications that have been developed as the main means of learning.

According to Driscol (2002) Blended learning is learning that combines or integrates a variety of web-based technologies, to achieve certain educational goals. Meanwhile, according to Semler (2005) Blended learning is a learning method that provides convenience by combining or integrating various ways of presenting teaching materials, teaching models, and learning styles that use various media to create communication between the facilitator and the trainee. So from the above understanding it can be concluded that blended learning is learning that integrates direct learning or face-to-face with online learning. The purpose of using Blended Learning is to combine 
Innovative Development of Mobile Application for Qibla Direction Guidance Services Training Fathurahman

direct learning and online learning into integrated entities so that the limitations of outreach can be overcome.

The term mobile learning can be interpreted as learning by the use of handheld and cellular information technology (IT) devices, such as cellular phones, tablets, and PCs such as laptops in teaching and learning. Mobile Learning is a part of electronic learning (e-Learning) so, by itself is also a part of distance learning.

Mobile learning is defined by Clark Quinn (2000) as: "The intersection of mobile computing and e-learning: resources that can be accessed wherever you are, strong search capabilities, rich interactions, strong support for effective learning, and assessment based performance. -Location learning in time or space. "Quoted by Theo Hug in his article titled Microlearning and mobile Learning in the Encyclopedia of Mobile Phone Behavior. Based on these definitions, mobile learning is learning that utilizes information and communication technology in the process. The concept of mobile learning brings the benefits of the availability of teaching materials that can be accessed anytime and anywhere, with attractive and complete presentations.

In line with the meaning of mobile learning that has been defined by Clark Quinn (2000) as: "an intersection of electronic learning and mobile computing is a resource that can be accessed wherever you are, by rich interaction, strong search capabilities and strong support for effective learning, and assessment based performance with learning locations that are not limited in time or space." This opinion was also quoted by Theo Hug in his article titled Microlearning and Mobile Learning in the Encyclopedia of Mobile Phone Behavior. Based on these definitions, the meaning of mobile learning is learning that utilizes information and communication technology in the process. The concept of mobile learning brings the benefits of the availability of teaching materials that can be accessed anytime and anywhere, with attractive and complete presentations.

\section{METHOD}

This research is a research and development (R\&D) by adapting the ADDIE model which consists of 5 stages namely analysis, design, development, implementation and evaluation.

\section{Analysis Stage}

At this stage the goal of developing web-based applications was set for application users both staff, Islamic religious technical staff and teachers in the Ministry of Religion Office of Kepulauan Seribu Regency or communities in need outside the Ministry of Religion Office environment. Analysis is carried out to identify and formulate the purpose of the development of this mobile application and for whom this application is used. This analysis phase is also a process of defining what the mentor participants will learn, namely conducting a needs assessment (identifying needs) and identifying problems (needs). Therefore, the output that will be produced is in the form of the characteristics of the guidance participants, the identification of problems and needs as well as a detailed analysis based on the needs. So that there are three objects to be analyzed include the following

a) Individual analysis is carried out to find out and clarify whether problems faced require solutions in the form of learning programs, for example: lack of interest, knowledge and skills of employees causes low index of services in organizations, this requires solutions in the form of organizing learning programs that can increase individual interest.

b) Performance Analysis is carried out in order to find out and clarify whether the problem of low service index that is faced requires a solution in the form of management improvement, for example: low achievement motivation or burnout in working requires 
management quality improvement solutions. For example, providing incentives for work performance or providing adequate work facilities.

c) Needs Analysis. Requirement analysis is a step needed to determine abilities or competencies that need to be learned to improve understanding of the concept of determining the direction of Qibla. This can be done if the training program is considered a solution to the HR competency problem that is being faced.

\section{Design Stage}

This stage is also known as making a design. Just like erecting a house, before the house is built, drawings of the house design are first made. In this design phase, the determination of the elements that need to be included in the mobile application to be developed, in accordance with the learning design that is the content aspect and the learning model that will be carried out. In developing this web-based application there are many choices of Programming Languages that can be applied, with the aim that the developed application can be accessed anytime and anywhere that runs on the Windows Server operating system, so in this study, the application source code will be written using ASP.net Programming Language. In addition, other supporting sources are also considered in the design, so that at this stage it can be determined whether the application can be developed in accordance with the objectives and results of the analysis.

\section{Development Stage}

The development phase is the process of realizing a design that has been prepared to become a reality. The application design in the design is then processed to be developed into a mobile application in accordance with the objectives and analysis results. All system requirements are met and coding (writing scripts and algorithms) applications begin by writing the script / source code in the ASP.net Language. An important step in this stage of development is testing the product prototype before it is implemented. This trial phase is indeed part of one of ADDIE's steps, which is evaluation. More precisely formative evaluation, because the results are used to improve the training and guidance system that is being developed.

\section{Implementation Stage}

Implementation is a concrete step to implementing the application that is being made. The developed application is arranged so that it can carry out its tasks, functions and roles so that it can be implemented. At this stage the developed application is then installed / installed on the hosting server so that it can be accessed by users through various web browsers. After the application is installed on the hosting server then it can then be implemented according to the initial design.

\section{Evaluation Stage}

Evaluation is the process of seeing whether the mobile application being built is successful, according to the initial design or not. Actually, the evaluation phase can occur at every four stages. Formative evaluation takes place at each of the four stages above because the aim is for revision needs. As in the design stage, we might need a form of formative evaluation such as expert review to provide input to the design we are making. At the development stage, trials of the products developed are also needed and small group evaluations are needed.

\section{Data Collection Technique}

Data collection techniques carried out by: documentation, interviews, observation, test implementation and questionnaires. Data was collected using two types of instruments namely test and non-test. Data collection is not a test that is observation, documentation, interviews and questionnaires. The data collection by testing is the implementation of pre-test and post-test. 
Innovative Development of Mobile Application for Qibla Direction Guidance Services Training Fathurahman

Before the instrument is used for data collection, the validity and reliability tests are first performed. Theoretical validity is carried out by experts and the empirical validity is carried out by testing the validity and reliability. The initial instrument validity test with a nominal measurement scale in the form of a dichotomy score was analyzed using the biserial point correlation technique and for the questionnaire instrument with an ordinal measurement scale the Product Moment correlation technique was used. The instrument reliability test with a nominal measurement scale uses Kruder Richardson-20 while the instrument reliability test with an ordinal measurement scale uses the reliability coefficient test (Alpha Cronchbach).

\section{Data Analysis Technique}

Data were analyzed using descriptive and inferential statistics. Descriptive analysis consists of the average score of the validation instrument, the maximum and minimum scores and the standard deviations. The activity to analyze this data is by summarizing the data that has been filled out by a validator to the table to be analyzed, then looking for the average of each measurement aspect in the instrument with the formula:

Information:

$$
x=\frac{\sum x}{N}
$$

$x=$ Average score of each aspect

$\sum x=$ Total Score

$N=$ Number of validators

The average score is transformed into a qualitative value in accordance with the criteria specified in the following table:

Table 1. Assessment criteria

\begin{tabular}{|c|c|}
\hline Score Interval & Criteria \\
\hline$x>M i+1.5(S D i)$ & Very Feasible \\
$M i<x<M i+1.5(S D i)$ & Feasible \\
$M i-1.5(S D i)<x<M i$ & Less Feasible \\
$x<M i-1.5(S D i)$ & Not Feasible \\
\hline
\end{tabular}

Information:

Mi $($ Median Rating Score $)=1 / 2 \times($ Max Score + Min Score $)$

SDi (Standard Deviation Rating Score $)=1 / 2 \times 1 / 3 \times($ Max Score - Min Score $)$

Inferential analysis consists of an $\mathrm{N}$-gain normality test to test the improvement in the results of guidance in determining the Qibla direction of trainees. Thus, the application developed can be said to be effective, based on the average participant mostly having a minimum N-Gain value in the medium category, which is formulated as follows:

$$
N-\text { Gain }=\frac{\text { Posttest Score }- \text { Pretest Score }}{\text { SMI }- \text { Pretest Score }}
$$

Information:

SMI = Ideal Maximum Score

With the criteria for the value of N - Gain as in the following table: 
Innovative Development of Mobile Application for Qibla Direction Guidance Services Training Fathurahman

Table 2. Criteria for the value of $\mathrm{N}-$ Gain

\begin{tabular}{|c|c|}
\hline Criteria Limits of N-Gain Values & Criteria \\
\hline$N-$ Gain $\geq 0.70$ & High \\
$0.30<N-$ Gain $<0.70$ & Middle \\
$N-$ Gain $\leq 0.30$ & Low \\
\hline
\end{tabular}

Table 3. Effectiveness of $\mathrm{N}-$ Gain Value

\begin{tabular}{|c|c|}
\hline Effective Limits of N - Gain Value & Criteria \\
\hline$>0.76$ & Very Effective \\
$0.56-0.75$ & Effective \\
$0.40-0.55$ & Less Effective \\
$<0.40$ & Not Effective \\
\hline
\end{tabular}

To measure the satisfaction level of using the Qibla direction guidance mobile application that has been developed, researchers adapted the survey procedure for service satisfaction according to the Minister of Administrative Reform and Bureaucracy Reform Regulation Number 14 of 2017 concerning Guidelines for Preparation of Community Satisfaction Survey Public Service Unit Units by adjusting survey elements according to service characteristics which was developed. Then the distribution of questionnaires needs to be done to determine the perception of respondents / service users on the level of satisfaction using the Qibla direction guidance mobile application. Based on these guidelines, calculation of the service satisfaction survey index is done by calculating the total value of service units obtained from the average number of each service element. While the composite index value (combined) for each service unit, is the sum of the average values of each service element multiplied by the weight of 0.167 (for 6 elements), as the following table:

Table 4. Elements and Value of Service Satisfaction Survey Elements

\begin{tabular}{|c|c|c|}
\hline Number & Elements & Value of Element \\
\hline 1 & Procedure & $a$ \\
\hline 2 & Time & $b$ \\
\hline 3 & Content & $c$ \\
\hline 4 & Product Specifications & $d$ \\
\hline 5 & Realibility & $e$ \\
\hline 6 & Accessibility & $f$ \\
\hline
\end{tabular}

To find out the value of the Service Unit Interval calculated using the following formula: $(a \times 0,167)+(b \times 0,167)+(c \times 0,167)+(d \times 0,167)+(e \times 0,167)+(f \times 0,167)=$ interval value $(X)$

To get the service satisfaction index value, the interval value obtained is multiplied by 25 so that the Service Quality and Service Unit Performance is obtained. The results of this multiplication are converted based on the following table:

Table 5. Conversion Value of Service Satisfaction Index

\begin{tabular}{|c|c|c|c|c|}
\hline $\begin{array}{c}\text { Perception } \\
\text { Value }\end{array}$ & Interval Value & $\begin{array}{c}\text { Conversion Value } \\
\text { (Index) }\end{array}$ & $\begin{array}{c}\text { Service } \\
\text { Quality }\end{array}$ & $\begin{array}{c}\text { Service } \\
\text { Performance } \\
\text { Value }\end{array}$ \\
\hline 1 & $1,00-2,5996$ & $25,00-64,99$ & $\mathrm{D}$ & Not Good \\
\hline 2 & $2,60-3,064$ & $65,00-76,60$ & $\mathrm{C}$ & Less Good \\
\hline 3 & $3,0644-3,532$ & $76,61-88,30$ & $\mathrm{~B}$ & Good \\
\hline 4 & $3,5324-4,00$ & $88,31-100,00$ & $\mathrm{~A}$ & Very Good \\
\hline
\end{tabular}


Innovative Development of Mobile Application for Qibla Direction Guidance Services Training Fathurahman

\section{RESULT AND DISCUSSION}

The development of this mobile learning application adapts the steps for the development of ADDIE, which is detailed in the following developments:

\section{Analisys Stage}

User analysis is performed to determine the characteristics of trainees in understanding the material under study. Based on interviews with the head of the Ministry of Religion at the Thousand Islands Regency Office, data and information were obtained that all Islamic religious technical personnel have different abilities from the average background of general education so that they have not mastered the technical abilities of Islamic religion such as determining the direction of Qibla, prayer times, and rukyat hilal (moon sight observation). Conditions are minimal supporting equipment facilities in providing religious services such as limited computer equipment connected to an adequate internet network.

The participants of this training were Islamic religious technical staff both at the Kepulauan Seribu Regency Office of the Ministry of Religion and at the District Office of Religious Affairs (KUA Kepulauan Seribu Utara dan KUA Kepulauan Seribu Utara). All of them have communication devices in the form of smartphones with the majority of Android-based phones. So that all are able to use mobile-based applications. Qibla Direction Determination is one of the services available in the Ministry of Religion of the Thousand Islands District, the service is an important service needed by the community considering that $100 \%$ of the population of the Kepulauan Seribu district embraces Islam and on each island there are mosques and prayer rooms.

The construction of worship facilities at each homestay in line with the government's encouragement in improving the tourism sector makes the need for Qibla direction determination services also increase. Difficulties experienced by technical staff in the District Office of the Ministry of Religion and the Office of Religious Affairs in the District are in understanding the concept of determining the direction of Qibla, carrying out the calculation process steps, explaining the coordinates of the measurement location and describing the direction of the Qibla direction towards the Kaaba. Furthermore, the process of training activities carried out so far only uses conventional technical guidance and does not utilize IT devices connected to the internet that are rich in information sources.

Based on observations, it appears that technical staff within the Regency Ministry of Religion Office and District Religion Affairs Office tend to use their cell phones to access social media, browse and communicate online, play games and other entertainment such as watching videos and listening to music and other features all of which have not been synergized with work assignments. Not only in offices outside of the office, technical staff use their cellphones at all times and even take up time and work concentration.

The above mentioned is one of the causes of the low performance of public services in the Ministry of Religion of the Kepulauan Seribu Regency, particularly in the guidance of Qibla direction. However, it is believed that the problem can be overcome by creating a mobile application that utilizes a smartphone in accessing Qibla direction guidance services as well as a training facility and the process of calculating the Qibla direction at each location wherever located.

The development and manufacture of mobile applications for Qibla direction guidance services by utilizing information technology and internet networks are expected to improve the ability of Islamic religious technical staff within the Ministry of Religion of the Kepulauan Seribu Regency. Making the application using Visual Studio .Net software with a web programming language that is ASP.net which is supported by the Windows Server operating system. Access to 
Innovative Development of Mobile Application for Qibla Direction Guidance Services Training Fathurahman

the application can use a browser on a PC or cellphone that is connected to the internet in multiplatform or by installing the browser application in apk format on an Android-based phone.

\section{Design Stage}

At this stage the application planning and design are carried out which includes: making the overall application design in the form of storyboards and compiling the application content to be created. After the storyboard and application content are made, the results are discussed and discussed together with the programmer to be evaluated and revised, so as to produce a good design. The direction of the design is to realize an application that can process Qibla direction calculation, provide output of Qibla direction calculation and provide an overview and guidance of Qibla direction determination at the measurement location wherever located

\section{Development Stage}

From the results of the design phase continued into the development stage. At this stage a flow chart from the storyboard and the results of the design is compiled to create the desired application in the form of a mobile application for guidance of Qibla. In the development phase, testing of applications that are made to see whether the application is valid and whether or not the application is appropriate is used. This assessment was carried out by a material expert validator who was an echelon IV official who mastered astronomy, echelon III officials in charge of the affairs of Islam and Falak sciences as well as team of qibla direction determination at the Regional Office of the Ministry of Religion of DKI Jakarta Province. The media expert validator was the IT expert from the RSCM, Mr. Sujiyanto, S.Kom and from the National Library of Indonesia namely Mr. Deni Syahreza, S.Kom (who is a software engineering and networking analyst at each institution).

After the testing process is done the results are evaluated to revise application development to produce validity and feasibility of learning media in the form of desired mobile applications, according to the design and needs analysis. The initial results of the development phase in the form of Product Draft I application, is the first mobile application created by researchers together with programmers. After Product Draft I was made to determine its quality as a good quality learning media, validation is needed by mobile application experts and material experts in the form of responses, suggestions and comments, before being tested on the training participants. The results of the validation from the mobile application expert and the material expert are then evaluated and analyzed to make revisions to produce a Product Draft II until the validator states that it is valid and feasible for a limited trial. The results of the analysis recap of the three validators are given in Figures below.

Figure 1. Product Draft Validation Results Chart in 4 Aspects of Assessment

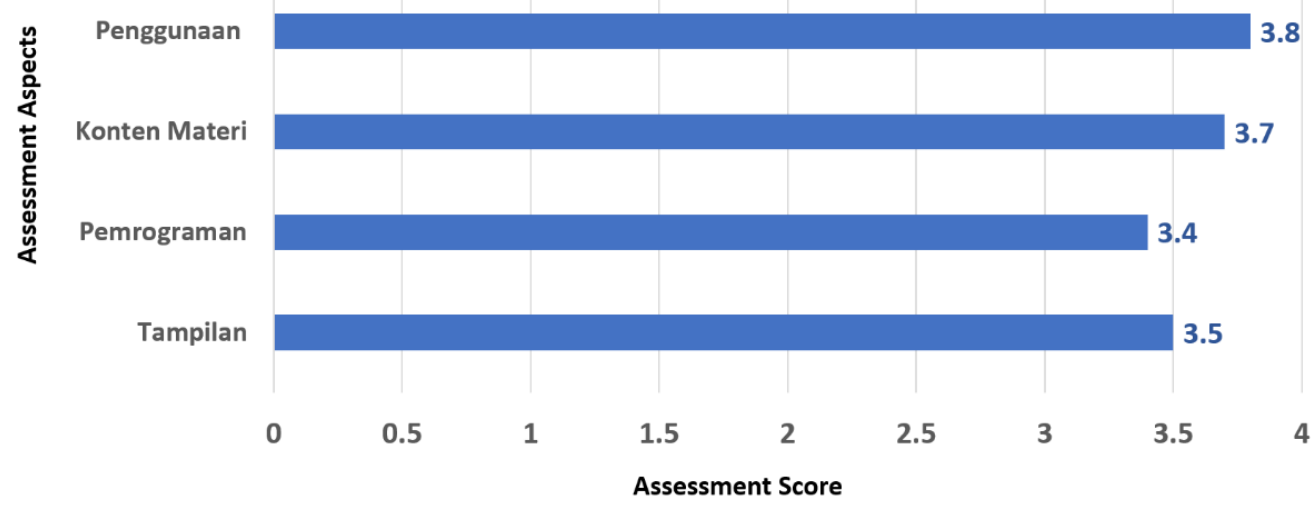


Innovative Development of Mobile Application for Qibla Direction Guidance Services Training Fathurahman

The results of the product validation analysis of the 4 (four) aspects of the assessment are the use, content material, programming and display with 5 indicators in each of these aspects obtained that the aspects of application development developed get the highest score with a score of 3.9 which is in the criteria of "very feasible ". Average validator values on the usage aspects are as follows:

Figure 2. Product Draft Validation Results in Usage Aspects Indicator

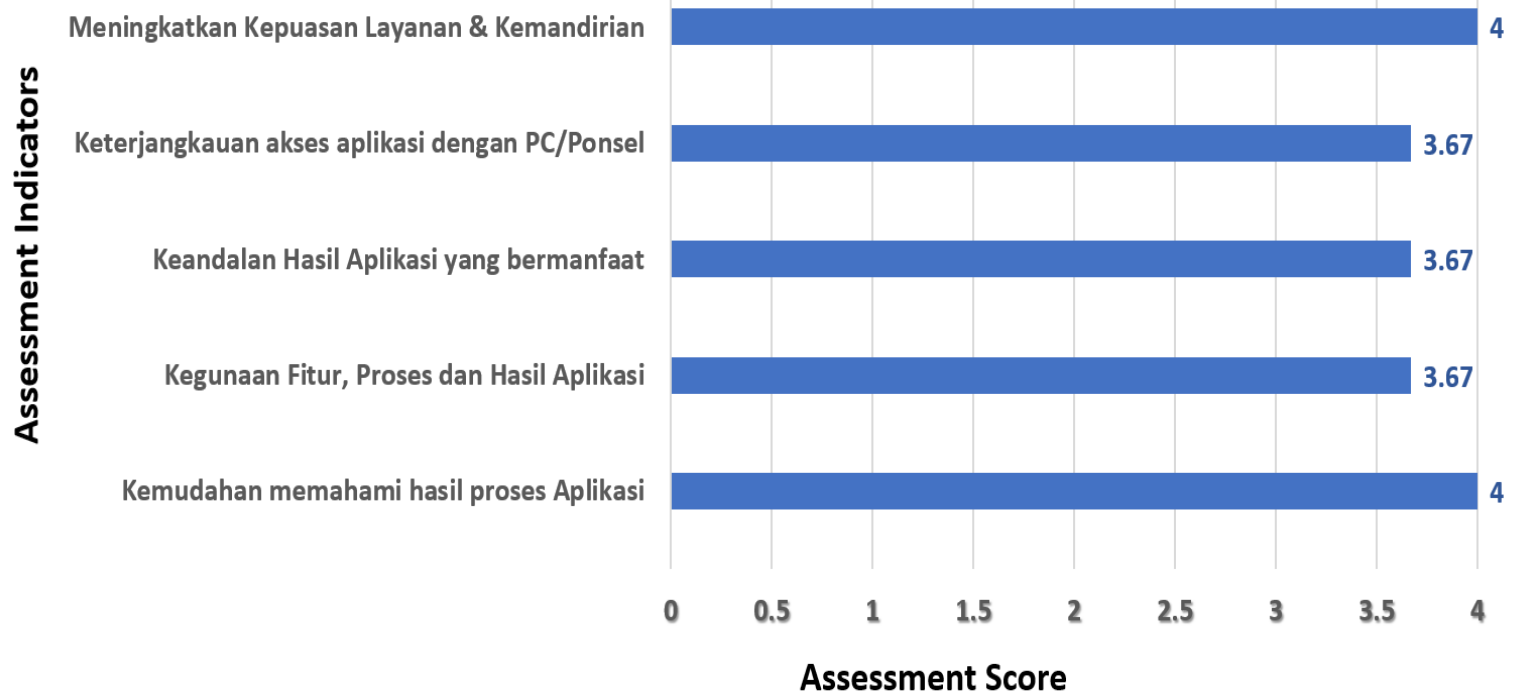

The results of the product validation analysis on the material content aspect are also in the "very feasible" criteria with a score of 3.7 with an average validator value as follows:

Figure 3. Product Draft Validation Results in Material Content Aspects Indicator

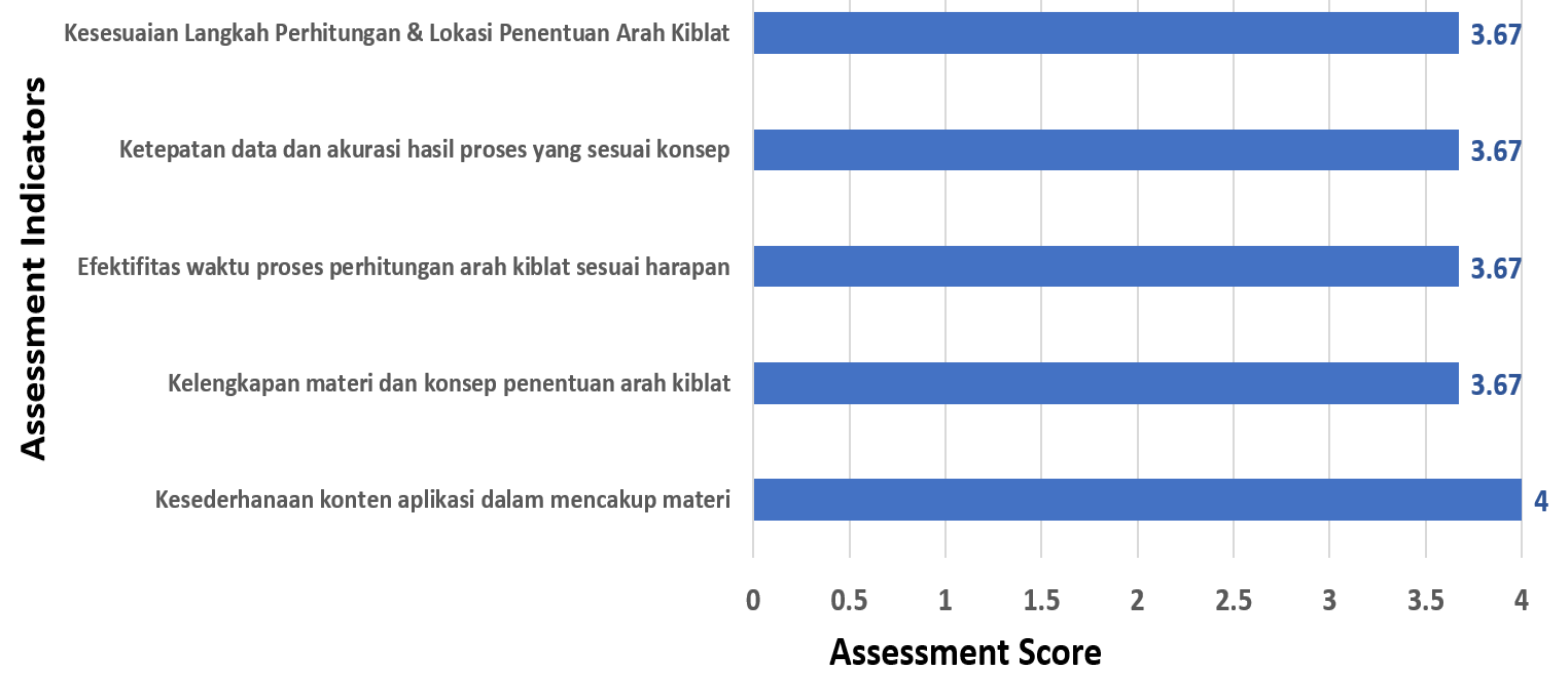

The results of the product validation analysis in the programming aspect are also in the "very feasible" criteria with a score of 3.4 with an average validator value as follows: 
Innovative Development of Mobile Application for Qibla Direction Guidance Services Training Fathurahman

Figure 4. Product Draft Validation Results in Programming Aspects Indicator

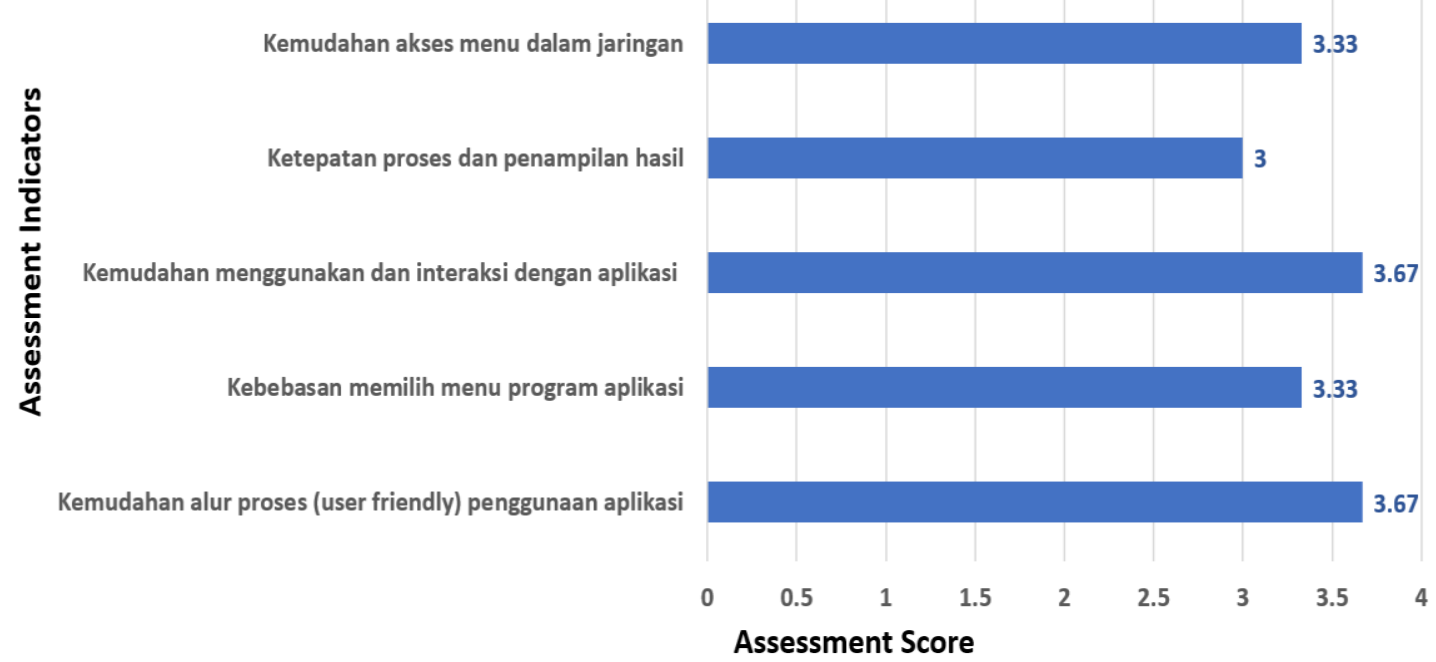

While the results of the product validation analysis on the display aspect are also in the "very feasible" criteria with a score of 3.5 with an average validator value as follows:

Figure 5. Product Draft Validation Results in Display Aspects Indicator

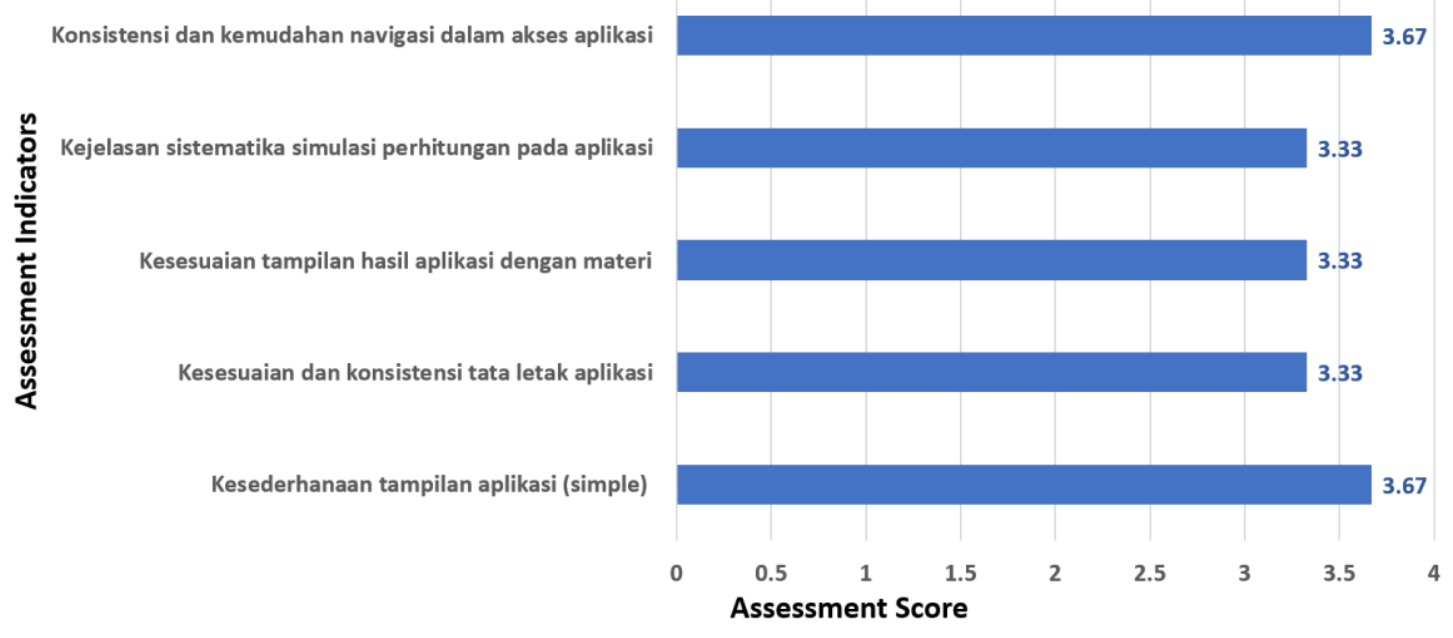

Based on the results of the analysis above and in accordance with the conclusions the results of the validation of the three validators show that the draft product that has been made is declared valid and appropriate for use with revisions in accordance with the suggestions and comments that have been submitted and then applied to the Draft Product II. In addition, analysis of the results of the validation of the contents of the three validators related to the test instrument grid which will be used to measure the results of the training is declared valid and can be used with no revisions.

\section{Implementation Stage}

The results of the development of the Draft Product II application and Test Instruments that were made before being trialled to the training participants, especially the validation assessment conducted by echelon III officials of the Head of Islamic Affairs in the Regional Office of the Ministry of Religion of DKI Jakarta Province IV then also The Head of Sharia Development Section in the Field of Islamic Affairs and 1 (one) member of the Qibla direction measuring team in the Regional Office of the Ministry of Religion of DKI Jakarta Province. The Draft Product II application is also used in the practice of measuring the direction of Qibla at the location of 3 
Innovative Development of Mobile Application for Qibla Direction Guidance Services Training Fathurahman

mosques and 3 prayer rooms in the DKI Jakarta province. Some suggestions, comments and input from the results of the validation trial at this stage are used to revise the product so that the resulting product meets the expectations and meets the needs analysis needs. The following are screenshots of the Qibla direction guidance mobile application on the Android phone:

Figure 6. Screenshots of Mobile Application for Qibla Direction Guidance Services
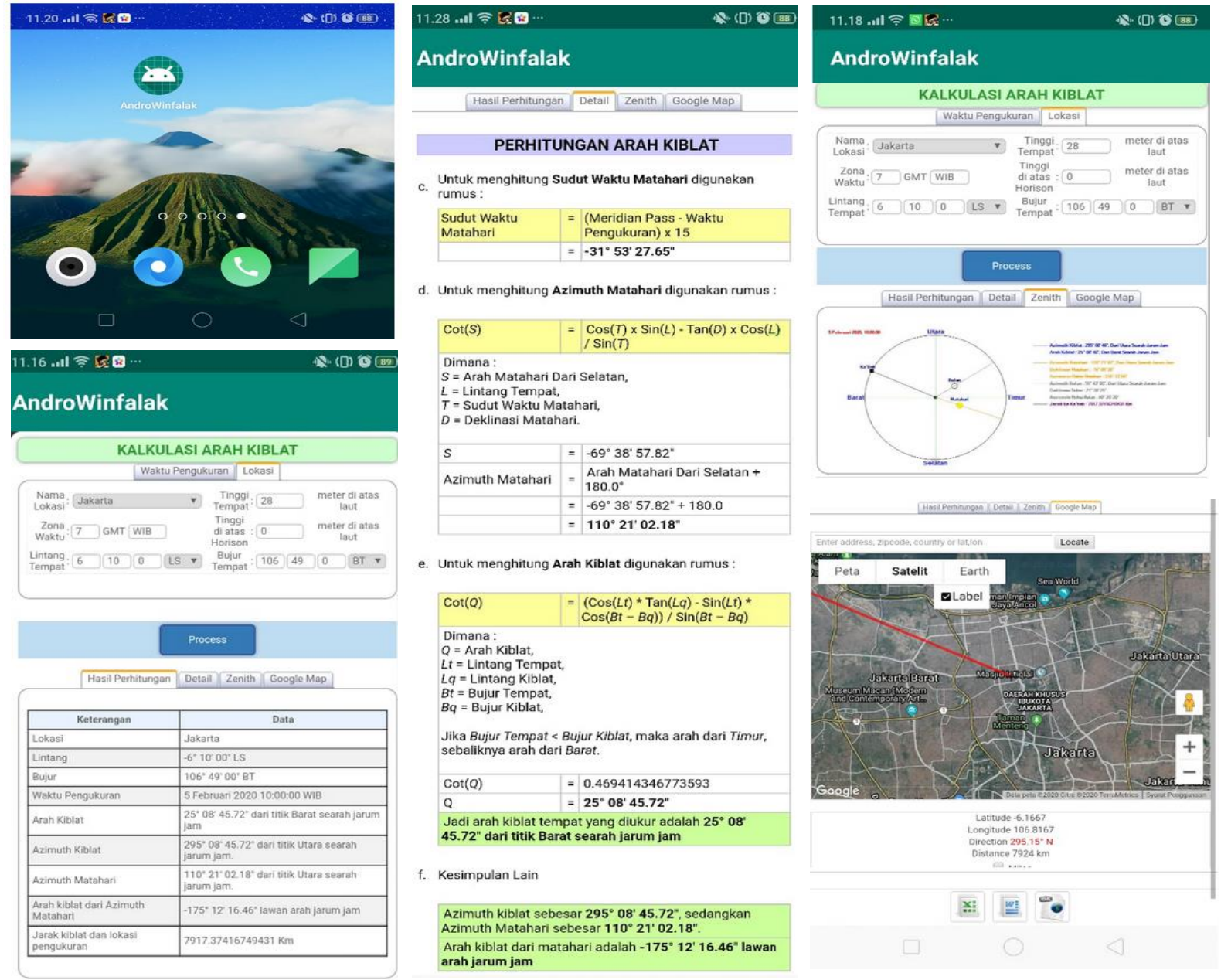

Qibla direction guidance service training was carried out on Pramuka Island, attended by 14 people, with 5 persons each form KUA sub-district delegation participants and 4 persons from the District Ministry of Religion Office. Before carrying out the activity, each participant was tested with a pre-test instrument. Qibla direction guidance service training based on mobile applications is carried out for three days with 24 Hours of Study which ends with the implementation of the post-test test.

\section{Evaluation Stage}

Formative evaluation is carried out at each stage / step of R \& D in this study in order to obtain the results of the development of mobile applications in accordance with the objectives. To find out the achievements of the guidance of Qibla training participants using this mobile application, the evaluation was carried out through pre-test and post-test, with multiple choice questions test instrument. Based on the results of the post-test, 6 participants received a score of 10 (100\% correct answers) with an average value of 14 participants being 9.21 . The following is an overview of the pre-test and post-test results of the training: 
Innovative Development of Mobile Application for Qibla Direction Guidance Services Training Fathurahman

Figure 7. Pre-test and Post-test Results

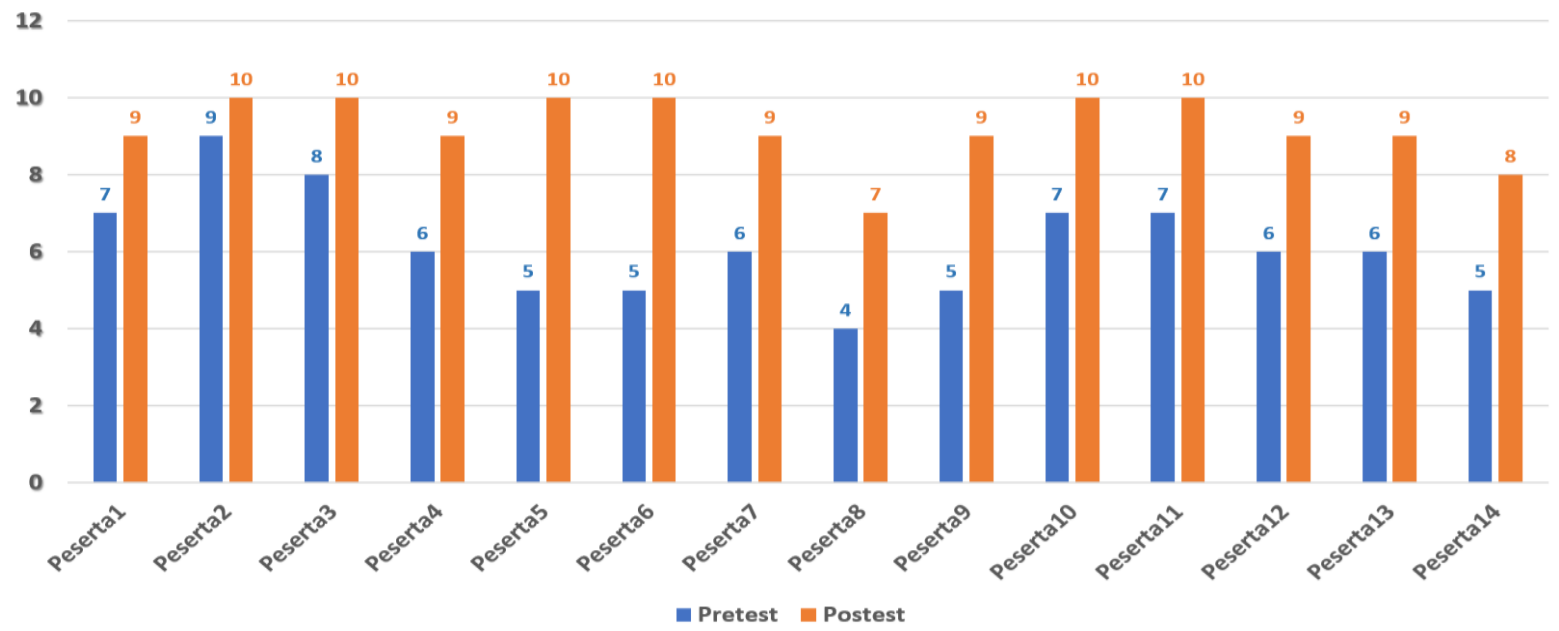

Data from the test results were analyzed by calculating the pre-test and post-test gain scores which were categorized as normal (N-gain). The results of the descriptive analysis of $\mathrm{N}$-gain before and after the use of the mobile application show that the Qibla Direction Guidance Service Training Participants obtain a minimum N-Gain value of 0.50 and a maximum of 1.0 with "Medium" and "High" Criteria, with an average N-Gain value all the participants were 0.82 , which was in the "high" category, with the effectiveness level in the "Very Effective" category with a standard deviation of 0.17 . The graph of the results of improving learning outcomes with N-Gain calculations is listed in the following figure:

Figure 8. N-Gain Value on Pre-test and Post-test Results

N-Gain

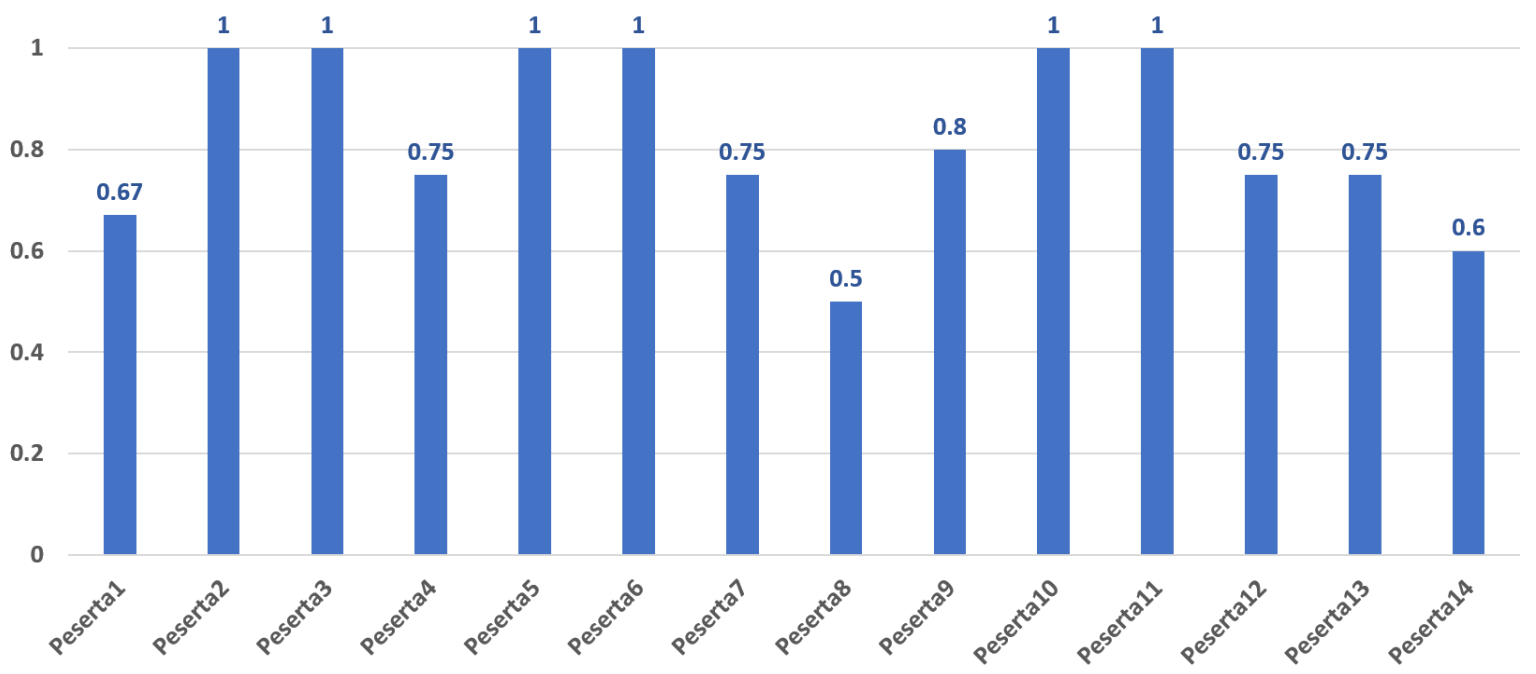

Inferential analysis is done by t-test. T test results at alpha 0.05 indicate the value of $t$ count is greater than the value of $\mathrm{t}$ table $(10.72>2.16)$, this shows that $\mathrm{H} 0$ is rejected, so it can be interpreted that there is a significant increase in the results of Qibla-based guidance training mobile application. After the testing step is carried out, a questionnaire is also distributed to measure the level of satisfaction of application usage in order to measure the use of mobile applications to improve the performance of public services in the Ministry of Religion of the Kepulauan Seribu Regency. with the following results: 
Innovative Development of Mobile Application for Qibla Direction Guidance Services Training Fathurahman

Figure 9. Mobile Application Service Satisfaction Survey Chart

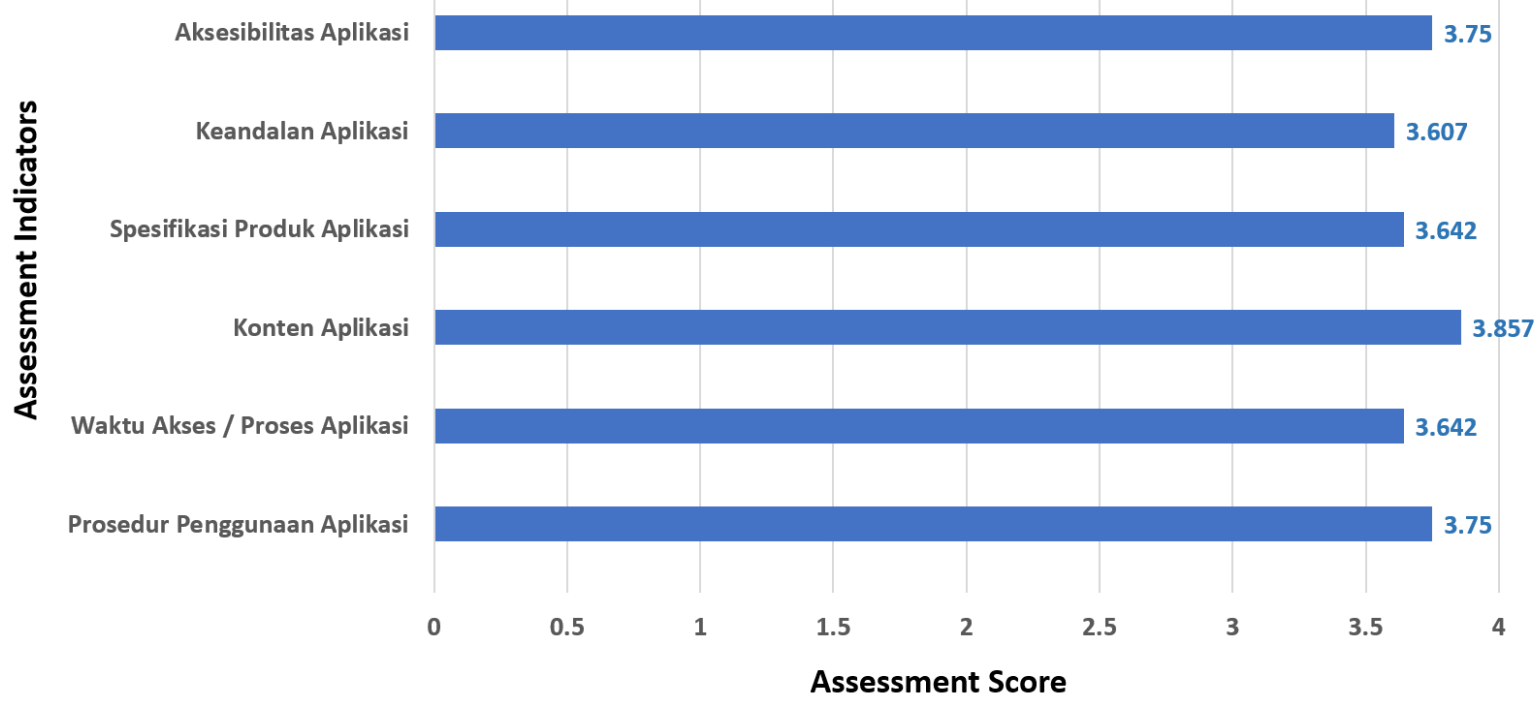

From the analysis of the Usage Satisfaction Survey, the interval value of 3.7157 was obtained so that the Service Satisfaction Index obtained was 92.89, which was in the "A" Service Quality and with "Excellent" Service Performance value.

\section{CONCLUSION}

Geographical and demographic constraints in the implementation of Qibla direction guidance services in the work area of the Office of the Ministry of Religion of the Kepulauan Seribu Regency can be overcome by using mobile applications that can be accessed online anytime, anywhere. Access to applications developed utilizing mobile phones has become a versatile tool in supporting the implementation of public service guidance for Qibla direction for the community. The mobile application that has been developed is not only useful as a learning tool but is also suitable for use in the practice of measuring the Qibla direction in various locations in the Kepulauan Seribu region. Although there are not many participants who realize that their smartphone is actually equipped with coordinate and direction sensors, so that with the mobile application, the guidance of the Qibla direction of the complete sensor available on an Android phone can be maximized for the benefit of public service performance for employees in the ministry of religion office of Kepulauan Seribu regency.

As the results of the implementation in this study can be stated that the purpose of developing this mobile based software has been achieved. So that the limitations of officers in providing Qibla direction determination services to the people in the thousand islands can be overcome by the guidance of Qibla which can be implemented by blended learning. With the existence of a mobilebased application, the time constraints of organizing the Qibla direction guidance service can also be overcome so that implementation can be carried out across time and place boundaries. The problem of affordability and coordination among the work units of the District Ministry of Religion Office and other technical issues that are constrained by the geographical location of offices and work units on different islands can also be overcome through the use of the internet as a communication tool and supporting the performance of public services. The results of the training that is applied with the blended learning model can improve participants' understanding, in this study can be concluded that the applications developed are of good quality and able to 
Innovative Development of Mobile Application for Qibla Direction Guidance Services Training Fathurahman

support efforts to improve the quality of public services. Thus, the development of mobile applications is expected to provide a stimulus for the emergence of other innovative ideas in order to overcome various problems encountered in the world of work, especially public services in the archipelago.

\section{REFERENCE}

Ahmad, J. (2017). Problematika Pendidikan Agama Islam (PAI) dalam Kurikulum 2013 dan Revisi 2013.

Arif, K (2011). Teknologi Pembelajaran PAI (Pendidikan Agama Islam) dalam Paradigma Konstruktivistik. Jurnal Fikroh. Vol 4 No. 2.

Arifin, M. (2010). Filsafat Pendidikan Islam: Edisi Revisi. Jakarta: Bumi Aksara.

Arifin, M (1987). Filsafat Pendidikan Islam. Jakarta: Bina Aksara.

Arifin, M. (2003). Ilmu Pendidikan Islam: Tinjauan Teoritis dan Praktis berdasarkan Pendekatan Interdisipliner. Jakarta: PT Bumi Aksara.

Ariyana, Y., et. al. (2018). Buku Pegangan Pembelajaran Berorientasi pada Keterampilan Berpikir Tingkat Tinggi. Jakarta: Kemendikbud.

Asnawan. (2010). Pendidikan Islam dan Teknologi Komunikasi. Jurnal Falasifa. Vol 1 No.2 September.

Azhari, S (2007). Ilmu Falak: Perjumpaan Khazanah Islam dan Sains Modern. Yogyakarta: Suara Muhammadiyah.

Barroso. J. \& Cabranes, Gomez, (2000). Face to face Learning Methodelogies vs Distance Meaning Methodologies: Case Study Online using Qualitive Analysis, International Conference Of Multimedia and ICT in Education 2000.

Barizi, A (2011). Pendidikan Integratif Akar Tradisi \& Integrasi Keilmuan Pendidikan Islam. Malang: UIN-Maliki Press.

Bersin, Josh, (2004). The Blended Bearning Book-Best Bractices, proven Methodologies, and Lesson Learned, San fransisco: Pfeiffer

Budiwati, A. (2015). Model Pembelajaran Integratif dalam Pengajaran Matakuliah Ilmu Falak II di

Program Studi Hukum Islam. International Conference: "Integration of Contemporary and Islamic Knowledge in Islamic Universitie Collaboration of Universitas Darussalam Gontor Indonesia, Universiti Sains Islam Malaysia, Universiti Sultan Sharif Ali Darussalam and Fatoni University Thailand.

Creswell, John W. (2009). Research Design Qualitative, Quantitative and Mixed Methods Approaches, California: SAGE Publication

Creswell, John W. (2015). Qualitatif Inquiry ang Research Design: Choosing Among Five Appoaches, terj. Ahmad Lintang Lazuardi, Yogtakarta: Pustaka Pelajar

Daryanto (2012). Model Pembelajaran Inovatif, Yogyakarta: Gava Media

Djamali, \& Fadhil, M. (1967). al Tarbiyah al insan al jadid. Tunisia al Syghly: Matba'ah al-ittihad alaam.

Djazaman, M. (2009). Konsep Pendidikan Islam. Jurnal Ilmu Pendidikan Islam. Volume 1.

Fauzi, A et. al (2019). Inovasi Pembelajaran Ilmu Falak Menggunakan CODACC. Edukasia: Jurnal Penelitian Pendidikan Islam.

Hapidz, Radif A. (2019). Desain dan Pembuatan Media Pembelajaran Mobile Learning pada Mata Pelajaran Sistem dan Instalasi Tata Udara. Journal of Mechanical Engineering Education, Vol. 6, No.1

Hasyim, A (2016). Metode Penelitian dan Pengembangan di Sekolah. Yogyakarta: Media akademi. 
Innovative Development of Mobile Application for Qibla Direction Guidance Services Training Fathurahman

Mardapi, D (2018). Teknik Penyusunan Instrumen Tes dan Non Tes. Yogyakarta: Parama Publisihing.

Khazin, M. (2008). Ilmu Falak dalam Teori dan Praktik. Yogyakarta: Buana Pustaka.

Margono, 2010. Metodologi Penelitian Pedidikan, Jakarta: Rineka Cipta.

Muhaimin. (2016). Bunga Rampai Penelitian dalam Pendidikan Agama Islam, STIT Muhammadiyah Berau.

Nawangsari, Dyah. (2010) Urgensi Inovasi Dalam Sistem Pendidikan, Jurnal Falasifa Vol.1 No. 1 Maret 2010.

Piskurich, G. M. (2015). Rapid Instructional Design: Learning ID Fast and Right, 3rd Ed. New Jersey: Wiley

Purwaningsih, D, \& Pujianto. (2009). Blended Cooperative E-learning (BCeL) sebagai sarana Pendidikan Penunjang Learning Community. Disampaikan dalam seminar nasional UNY dengan tema "Peranan ICT (Information and Comunication Technology) dalam pembelajaran" pada tanggal 25 juli 2009 di ruang sidang Utama Rektorat UNY.

Qulub, Siti T. (2018). Integrasi Astronomi dalam Ilmu Falak di PTAI dan Pondok Pesantren. Jurnal Al-Qanun. Vol. 21 No.2, UIN Sunan Ampel.

Rogers, Everet M.. (1983). Diffusion of Innovations. New York, Amerika Serikat: The Free Press.

Safaat, Nazrudin (2013). Pemograman Aplikasi Mobile Smartphone dan Tablet PC Berbasis Android. Bandung: Informatika.

Sari, Ira W. (2018). Aplikasi Mobile Learning Berbasis Android sebagai Media Pembelajaran pada Materi Program Linear Kelas XI di SMA Widya Dharma Surabaya. Journal of Mathematics Education, Science and Technology, Vol.3 No.2.

Smaldino, Sharon E. (2012). Instructional Technology \& Media for Learning Teknologi Pembelajaran dan Media untuk Belajar. Penterjemah: Arif Rahman. Jakarta: Kencana

Syahri, A. (2018). Spirit Islam dalam Teknologi Pendidikan di Era Revolusi Industri 4.0. Jurnal Attarbiyah, Volume 28.

Syukur, A (2016). Revitalisasi Teknologi Pendidikan Islam. Jurnal Tadris, Vol. 11 No.2.

Tidjani, A. (2017). Manajemen Lembaga Pendidikan Islam Menghadapi Tantangan Globalisasi. Jurnal Reflektika Volume 13, No. 1

Walder, Anne M. (2014). The Concept of Pedagogical Innovation in Higher Education. Education Journal Vol.3 No.3.

Wahid, A (2008). Isu-isu Kontemporer Pendidikan Islam. Semarang: Need's Press Hal. 28.

Wibawa, B. et. al. (2014). Metode Penelitian Pendidikan. Tangerang Selatan: Universitas Terbuka Yan, Z (2015). Encyclopedia of Mobile Phone Behavior. New York: University at Albany.

Yunus, Razali (2018). Teori Belajar Sibernetik dan Implementasinya dalam Pelaksanaan Diklat. Journal of Education Science Vol.4 No.2, UUI

Zajda, J. (2015). Second International Handbook on Globalisation, Education and Policy Research. East Melbourne, Australia: Springer.

Zuhairini. (2015). Filsafat Pendidikan Islam. Jakarta: Bumi Aksara. 